JPKM, Vol.4, No.1, September 2018, Hal 87 - 108 DOI: http://doi.org/10.22146/jpkm.30292

ISSN 2460-9447 (print), ISSN 2541-5883 (online) Tersedia online di http://jurnal.ugm.ac.id/jpkm

\title{
Teknologi Tepat Guna pada Induk Kambing Melalui Penerapan Breeding Center dan Flushing di Sentra Peternakan Rakyat Kebon Wulangreh, Desa Karangdukuh, Klaten
}

\author{
I Gede Suparta Budisatria ${ }^{1}$, Nono Ngadiyono ${ }^{2}$, Bayu Atmoko ${ }^{3}$, Febri Ariyanti ${ }^{4}$ \\ Panjono $^{5}$, Endang Baliarti ${ }^{6}$, Tri Satya Mastuti Widi ${ }^{7}$, dan Danang Yulianto ${ }^{8}$ \\ ${ }_{1,2,3,5,6,7,8}$ Departemen Produksi Ternak, Universitas Gadjah Mada \\ ${ }^{4}$ Program Studi Kesehatan Hewan, Universitas Gadjah Mada \\ *budisatria@ugm.ac.id
}

Submisi:14 November 2017; Penerimaan: 13 Agustus 2018

\begin{abstract}
ABSTRAK
Ternak kambing di Desa Karangdukuh masih dipelihara secara tradisional di pekarangan rumah dan digembalakan di area persawahan. Terbatasnya skala kepemilikan dan tersebarnya lokasi kandang menyebabkan birahi sulit terdeteksi, tidak adanya pejantan unggul menyebabkan penurunan mutu genetik. Konsep breeding center merupakan penyediaan pejantan unggul dan kandang kawin dalam satu lokasi. Guna menunjang peningkatan kinerja induk perlu adanya perbaikan pakan selama kambing berada di area breeding center yaitu dengan flushing. Mitra kegiatan pengabdian adalah peternak di Sentra Peternak Rakyat Kebon Wulangreh di Desa Karangdukuh, Jogonalan, Klaten. Kegiatan dilaksanakan pada bulan April sampai Oktober 2017. Kegiatan dimulai dengan sosialisasi, dilanjutkan dengan pembelajaran masyarakat mengenai materi pengabdian. Selanjutnya adalah pemberdayaan peternak dalam membangun breeding center yang terdiri dari kandang kawin, kebun hijauan, sumur bor, dan instalasi listrik. Setelah breeding center lengkap, maka konsep tersebut diaplikasikan. Breeding center merupakan solusi sederhana bagi peternak dalam mendeteksi berahi induk dan adanya keterbatasan pejantan unggul, kesehatan ternak lebih terkontrol, peningkatan kualitas genetik dan kinerja induk dapat dicapai, sehingga produksi anak meningkat dan berdampak pada kesejahteraan peternak. Kegiatan pengabdian berjalan sesuai target dan mendapatkan respon yang sangat posistif dari peternak. Peternak bergotong-royong membangun area breeding center dan sudah dimanfaatkan. Peternak mampu membuat flushing dan akan diteruskan secara mandiri.
\end{abstract}

Kata Kunci: breeding center; flushing; panen cempe; teknologi tepat guna; ternak kambing,

\section{ABSTRACT}

Goat farms in Karangdukuh are still traditionally maintained in the yard of the house and grazed in the fields. The scale of ownership and the spread of the farm location make estrous detection so difficult, the absence of superior buck leads to a genetic quality degradation. The concept of breeding center is the provision of superior buck and mating house in one location. To support the increase of the does performance need for improvement of feed during in the breeding center, namely flushing. The partners of community engagement are farmers at Sentra Peternak Rakyat Kebon Wulangreh in Karangdukuh, Jogonalan, Klaten. It 
was done from April to October 2017. Activities began with socialization, followed by community learning and then was done the empowerment of farmers for built a breeding center was consisting of mating house, pasture, arteis well and electrical installation. The breeding center concept was applied after complete. Breeding center is a simple solution for estrous detecting and limitation of superior buck, more controlled does health, improvement for genetic quality and performance, so that kids crop can be increases and finally impact on the farmer prosperity. Enggagement activities already done on target and get very postive responses. Farmers have doing together to build a breeding center area and have been used. They are able to make flushing and will be continued independently.

Keywords: breeding center, flushing, kids crops, appropriate technology, goat

\section{PENDAHULUAN}

Desa Karangdukuh, Kecamatan Jogonalan, Kabupaten Klaten dahulu merupakan kawasan pertanian yang subur. Sebagian besar masyarakatnya bertani dan beternak. Sebagaimana kawasan pertanian lainnya, desa tersebut mampu menghasilkan padi berlimpah, sehingga masyarakat desa menggantungkan hidupnya dari hasil bumi. Sejak tahun 1980-an terjadi masa paceklik, desa tersebut mulai menghadapi masa-masa sulit dimana hasil bumi tidak mampu mencukupi kebutuhan hidup. Sebagian besar masyarakat mulai beralih profesi sebagai pengrajin bata merah. Akan tetapi, produksi bata merah justru memberikan dampak terhadap kerusakan lahan pertanian desa. Alih fungsi lahan pertanian tidak mampu memberikan nilai tambah bagi sumber daya alam, seperti halnya sebagai lahan pertanian. Guna merangsang masyarakat desa kembali memanfaatkan lahan pertanian maka dilakukan inisiasi dan penggalakkan usaha peternakan, yaitu antara lain ternak sapi, kambing, itik, burung, dan ikan.

Ternak kambing merupakan salah satu komoditas yang sedang dikembangkan oleh masyarakat Desa Karangdukuh, pada tahun 2016 dibentuk kelompok ternak kambing "Mekar Sari” dengan badan hukum Keputusan Menteri Hukum dan HAM Republik Indonesia nomor AHU-0069999.AH.01.07.2016. Kelompok Mekar Sari beranggotakan 24 peternak. Sejak Januari 2017 seluruh kelompok ternak bergabungan membentuk Sentra Peternakan Rakyat (SPR) Kebon Wulangreh dengan tujuan untuk mempermudah koordinasi dan memperkuat eksistensi kelompok ternak. Berkat bantuan APBDes dan KODIM 0723/Klaten dibangunlah kandang kambing terpadu di lahan kas desa. Namun demikian, hingga saat ini kandang terpadu masih belum dimanfaatkan 
secara optimal. Dikarenakan masih adanya beberapa kendala yang dihadapi seperti belum adanya ketersediaan air bersih, instalasi listrik, lahan pakan, dan pejantan unggul.

Ternak kambing memiliki peranan yang penting dalam sistem usaha pertanian di Indonesia. Secara sosial ekonomi, ternak kambing merupakan ternak yang sebagian besar dipelihara oleh peternak rakyat sebagai penghasil daging, susu, pupuk, kulit, sebagai tabungan dan asuransi serta sebagai sarana pemerintah dalam pengentasan kemiskinan di beberapa daerah. Secara sosial budaya ternak kambing berperan dalam perayaan keagamaan dan budaya yang sudah menjadi tradisi masyarakat Indonesia. Usaha pemeliharaan ternak kambing di pedesaan umumnya masih dilaksanakan secara tradisional, sangat tergantung pada ketersediaan input alam dan hijauan-hijauan lain yang tersedia di lokasi sekitarnya dan tidak tersedia pejantan unggul menyebabkan terjadi perkawinan sedarah (inbreeding) secara terus menerus, sehingga menurunkan mutu genetik ternak. (Budisatria \& Santoso, 2009; (Budisatria et al., 2010).

Konsep breeding center merupakan sistem penyediaan pejantan unggul dan kandang kawin dalam satu lokasi. Perkawinan akan terjadi secara alami dengan mencampur induk dan pejantan dalam satu kandang kawin selama kurun waktu tertentu. Breeding center merupakan solusi sederhana untuk mengatasi permasalahan peternak dalam mendeteksi berahi induk kambing dan keterbatasan pejantan unggul untuk mengawini induk kambing. Selain itu, kesehatan ternak lebih terjamin dan terkontrol selama berada di breeding center dan peningkatan kualitas genetik serta kinerja induk dapat dicapai. Produksi cempe dapat meningkat dan pada akhirnya berdampak pada peningkatan kesejahteraan peternak. Hasil penelitian (Widi et al., 2016) menunjukan bahwa introduksi pejantan unggul dapat meningkatkan produktivitas anak yang dihasilkan. Adanya introduksi pejantan unggul kambing Peranakan Etawah di kelompok ternak Purwo Manungggal, Gunung kidul dapat meningkatkan pertambahan bobot badan harian $(\mathrm{PBBH})$ dan ukuran tubuh secara signifikan dibandingkan dengan sebelum keberadaan pejantan tersebut.

Peningkatan kinerja induk belum bisa tercapai apabila tidak diikuti dengan perbaikan mutu pakan yang diberikan selama kambing berada di breeding center. Kondisi kekurangan pakan pada induk akibat menyusui anaknya menyebabkan perkembangan reproduksi berjalan lambat. Menurut (Wardhani et al., 1997), pemberian 
pakan ternak yang berkualitas baik dan dalam jumlah yang cukup untuk sepanjang tahun dalam upaya peningkatan produktivitas ternak, tidak mungkin dilakukan karena keterbatasan modal yang dimiliki petani. Pemberian pakan tambahan yang berkadar protein tinggi pada saat-saat kritis dimana pada waktu tersebut induk kambing membutuhkan gizi yang baik dalam jumlah yang cukup, merupakan salah satu upaya untuk melaksanakan efisiensi biaya pakan. Metode tersebut dikenal dengan istilah flushing, flushing diterapkan baik pada periode satu bulan sebelum ternak induk dikawinkan, satu bulan sebelum induk melahirkan sampai pada waktu menyusui. Flushing nyata bermanfaat dalam usaha untuk meningkatkan keberhasilan program perkawinan, mengurangi angka kematian anak prasapih serta menambah kemungkinan kelahiran anak kembar.

Hasil penelitian (Socheh et al., 2011), menunjukkan bahwa peningkatan bobot badan harian $(\mathrm{PBBH})$ pada kelompok flushing lebih tinggi daripada kelompok nonflushing. Tanggap berahi kambing betina dewasa pada kelompok flushing dan nonflushing menghasilkan masing-masing sebanyak 100\%. Awal birahi kambing betina dewasa pada kelompok flushing lebih cepat daripada kelompok non-flushing. Birahi pada kelompok flushing lebih lama daripada kelompok non-flushing. Disimpulkan bahwa flushing pada kambing Kejobong betina dewasa dapat meningkatkan PBBH, mempercepat timbulnya awal berahi dan memperpanjang lama berahi.

Teknologi pengolahan pakan flushing dapat digunakan untuk memperbaiki status nutrisi induk kambing yang akan dan telah dikawinkan. Diharapkan dengan teknologi tersebut dapat mempercepat perkembangan proses reproduksi dengan munculnya berahi dan meningkatkan angka kebuntingan. Kemudian juga dapat digunakan pada induk bunting untuk memelihara anak selama dalam masa kebuntingan, sehingga status kesehatan dan panen anak (cempe) dapat meningkat. Teknologi flushing diaplikasikan dengan memanfaatkan formulasi ransum dari hasil-hasil penelitian yang pernah dilakukan oleh penulis sebelumnya (Munawaroh et al, 2015; Ngadiyono et al., 2014; Nuraini et al., 2014). Penerapan breeding center dan flushing jika dipadukan akan sangat efisien sebagai alternatif pemecahan masalah di kelompok ternak kambing.

Hilirisasi hasil riset mengenai produktivitas ternak ruminansia kecil oleh tim, salah satunya kambing dengan penerapan breeding center dan flushing di SPR Kebon 
Wulangreh ini sesuai dengan prioritas penghiliran riset UGM. Kegiatan pengabdian ini bertujuan untuk: 1) penghiliran dan transfer teknologi hasil riset yang telah dilakukan sebelumnya di bidang ternak kambing, khususnya teknologi reproduksi dan pengolahan pakan, 2) pembentukan kawasan sentra peternakan kambing rakyat, 3) meningkatkan kemampuan pemeliharaan ternak kambing di skala peternak rakyat, 4) meningkatkan status kesehatan ternak dan meningkatkan kinerja induk.

Beberapa tahun belakangan ini tantangan dalam dunia peternakan skala rakyat di Indonesia semakin tinggi, terlebih dengan tingginya alih fungsi lahan pertanian (produktif) menjadi lahan pemukiman dan pertambangan. Sehingga diperlukan suatu terobosan baru yang mampu meningkatkan ketrampilan peternak rakyat dan produktivitas ternak yang dipelihara. Breeding center merupakan konsep penerapan teknologi dalam rangka memudahkan peternak rakyat dalam pengelolaan atau pemeliharaan ternaknya, mengontrol status kesehatan ternaknya, memudahkan deteksi birahi dan perkawinan dengan pejantan unggul, sehingga berdampak terhadap produktivitas ternak dalam panen anak. Selain berfokus terhadap konsep pemeliharaan dan perkawinan, pada kegiatan ini juga dilakukan terobosan terkait dengan pakan ternak. Keberhasilan pemeliharaan sangat dipengaruhi faktor pakan sebesar $70 \%$, sehingga perlu adanya inovasi dalam skema breeding center sebagai bentuk kombinasi teknologi untuk dikembangakan bersama. Teknologi pengolahan pakan flushing menjadi alternatif dalam meningkatkan nilai nutrisi pakan yang akan diberikan pada induk-induk kambing yang akan dikawinkan dan induk yang sedang bunting, selain itu teknologi pakan dapat meringankan beban peternak dalam mencari pakan setiap hari, karena pakan dapat diawetkan terlebih dahulu, mempermudah pemberian dan mencegah sisa pakan yang terlalu banyak (tidak efisien).

Kombinasi kedua teknologi ini belum pernah dilakukan pada satu lokasi/kelompok ternak untuk menjawab dua permasalahan utama yang selalu terjadi di tingkat peternak rakyat, yaitu aspek reproduksi dan aspek nutrisi. Kebanyakan kegiatan yang sudah berjalan berfokus terhadap satu aspek permasalahan saja yaitu pakan/nutrisi, seperti teknologi pengolahan pakan untuk meningkatkan nilai nutrisinya tanpa mempertimbangkan faktor kemudahan dalam penerapanya dan kebutuhan nutrisi ternaknya, sehingga dirasa justru kurang efektif. Formulasi pakan flushing yng 
diterapkan ini hanya khusus dimanfaatkan untuk induk kambing dengan pemenuhan kebutuhan nutrisi yang sesuai berdasarkan hasil-hasil penelitian terbaru yang pernah dilakukan sebelumnya. Nutrisi menjadi faktor utama dalam performan induk, sementara konsep breeding center menjadi kunci keberhasilan perkawinan. Melalui transfer teknologi tepat guna berupa kombinasi breeding center dan flushing diharapkan peternak dapat menerapkan teknologi yang mudah dan murah. Manfaat lain bagi peternak dalam skala kelompok yaitu mampu meningkatkan kapasitas kelompok ternak dalam memanfaatkan teknologi. Keberhasilan pengembangan dan penerapan teknologi di Sentra Peternakan Rakyat tersebut dapat dijadikan role model yang dapat diaplikasikan maupun diterapkan pada kelompok ternak lainnya maupun pada komoditi ternak, seperti domba dan sapi.

\section{MASALAH}

Saat ini ternak kambing di Desa Karangdukuh masih dipelihara secara tradisional di pekarangan rumah dan digembalakan di sekitar area persawahan. Produktivitas dan tingkat kesehatan ternak kambing yang dipelihara masih tergolong rendah. Hal ini disebabkan karena sistem pemeliharan yang dilakukan oleh peternak masih tradisional dan belum adanya sentuhan serta adopsi terknologi. Terbatasnya skala kepemilikan ditambah dengan tersebarnya lokasi kandang menyebabkan berahi/estrus sulit terdeteksi, tidak adanya pejantan unggul juga menyebabkan penurunan mutu genetik ternak.

Selain kondisi di atas, faktor kecukupan nutrisi menjadi sangat penting dalam upaya peningkatan produktivitas induk. Kondisi kekurangan nutrisi pada induk akibat menyusui anaknya dapat menyebabkan perkembangan reproduksinya berjalan lambat, sehingga akan memperpanjang jarak beranak. Pada induk bunting, kekurangan nutrisi juga akan berdampak buruk terhadap induk dan janin. Maka dari itu, dibutuhkan langkah terobosan sebagai alternatif solusi permasalahan tersebut. Target dari kegiatan ini adalah partisipasi aktif peternak dalam setiap kegiatan, peternak berminat dan bersedia mengadopsi teknologi yang diintroduksi, peternak termotivasi untuk mengubah cara beternak yang bersifat individual dan tradisional menjadi secara berkelompok, terorganisir dan tercatat dengan menerapkan konsep breeding center. 


\section{METODE}

\subsection{Kelompok Sasaran dan Waktu Kegiatan}

Kelompok sasaran pada kegiatan pengabdian ini adalah para petani-peternak yang tergabung di Sentra Peternak Rakyat (SPR) Kebon Wulangreh pada khususnya, dan secara umum adalah warga masyarakat Desa Karangdukuh, Kecamatan Jogonalan, Klaten. Kegiatan ini dilaksanakan pada bulan April sampai dengan Oktober 2017.

\subsection{Metode Pelaksanaan}

Pelaksanaan kegiatan pengabdian kepada masyarakat ini dilakukan dengan tahapan metode sebagai berikut:

a. Sosialisasi

Sosialisasi kegiatan pengabdian dilakukan kepada peternak sebagai tahap awal, dalam sosialisasi disampaikan mengenai maksud dan tujuan serta perizinan kepada peternak beserta perangkat desa. Bersama pada saat kegiatan sosialisasi, juga dilakukan pretest pada peternak untuk mengetahui sejauh mana tingkat pemahaman terhadap kegiatan pengabdian yang akan dilakukan.

b. Pendidikan Masyarakat

Penyuluhan merupakan kegiatan kedua yang perlu disampaikan kepada peternak sebagai tindak lanjut dari apa yang sudah disosialisasikan. Tujuannya adalah untuk memberikan wawasan dan pengetahuan serta pembekalan ilmu mengenai ternak kambing. Kegiatan penyuluhan ini dilakukan menggunakan materi yang sudah disiapkan. Materi penyuluhan yaitu tentang beternak kambing yang meliputi manajemen pemeliharaan, manajemen perkandangan, manajemen pakan, manajemen reproduksi, perawatan kesehatan, dan pemanfaatan limbah. Buku panduan praktis dan sederhana yang sangat mudah untuk dibaca, dipahami, dan diaplikasikan oleh peternak juga turut diberikan pada kegiatan penyuluhan sebagai salah satu media pembelajaran, agar peternak dapat belajar secara mandiri setelah mengikuti kegiatan ini.

c. Demonstrasi dan pelatihan

Demonstrasi dan pelatihan dilaksanakan setelah melakukan penyuluhan, dalam kegiatan pengabdian ini dilakukan praktek dan pelatihan pada peternak untuk 
teknologi pengolahan pakan, yaitu flushing. Demonstrasi dan pelatihan bertujuan untuk memberikan pemahaman yang lebih terhadap apa yang sudah disampaikan pada materi penyuluhan. Pembuatan pakan flushing diawali dengan demonstrasi cara pembuatannya. Peternak diberi pengetahuan tentang bahan pakan yang akan digunakan dan proses pembuatannya, dengan demonstrasi cara pembuatan flushing secara langsung diharapkan peternak dapat aktif berperan dalam kegiatan dan ada komunikasi dua arah. Pakan yang sudah jadi kemudian diuji coba dengan diberikan langsung ke ternak, dan diuji kualitas nya secara analisis proksimat di Laboratorium Ilmu Makanan Ternak, Fakultas Peternakan, UGM. Media poster yang berisi tentang bahan pakan, dan metode pembuatan flushing dibuat dan dipasang di area breeding center untuk mempermudah peternak dalam mengingat dan mempraktekkan pembuatan flushing secara mandiri.

d. Pemberdayaan Peternak

Kegiatan pemberdayaan bertujuan untuk menggerakkan peternak agar dapat berpartisipasi aktif dalam kegiatan pengabdian dan secara tidak langsung akan meningkatkan rasa kebersamaan dan gotong royong antar peternak. Kegiatan pemberdayaan meliputi pembangunan kandang kawin sebagai breeding center, penanaman hijauan pakan ternak kambing, pembuatan sumur bor sebagai sumber air bersih dan instalasi listrik di area breeding center.

e. Pembuatan kandang kawin

Kegiatan pembuatan kandang kawin dilakukan di area kandang terpadu milik SPR Kebon Wulangreh, dimulai dengan diskusi dan menyusun desain kandang sesuai lokasi/area dan kapasitas, setelah disepakati kemudian dilakukan pengadaan bahan dan peralatannya. Peternak membangun kandang kawin secara bergotong royong. Untuk memastikan bahwa kandang dibuat sesuai dengan desain, maka tim pengabdian melakukan kunjungan ke lokasi. Setelah kandang kawin berdiri maka tim menyiapkan pejantan unggul yang akan digunakan sesuai dengan bangsa kambing yang dipelihara. Setelah kandang kawin sudah selesai dibangun dan pejantan unggul siap digunakan, maka tim menyampaiakan konsep breeding center yang akan diadopsi peternak. Media yang digunakan yaitu melalui pertemuan rutin dan melalui media poster. 
f. Monitoring dan Evaluasi

Monitoring dan evaluasi dilakukan dengan melihat dan mengukur indikator kinerja dan capaian dari kegiatan pengabdian ini. Pengukuran indikator dilakukan dengan mengadakan wawancara dengan peternak dan pengukuran/pencatatan pada ternak mereka di awal dan akhir kegiatan. Wawancara dilakukan dengan menggunakan kuesioner (pretest dan posttest). Indikator kinerja dari kegiatan ini meliputi adopsi sistem perkawinan oleh kelompok ternak dan peningkatan kinerja kambing yang dipelihara. Adanya adopsi sistem dilihat berdasarkan tingkat kemandirian peternak dalam melaksanakan sistem pemeliharaan dan perkawinan ternak. Peningkatan kinerja kambing dilihat berdasarkan angka kebuntingan dan panen anak (cempe). Penggunaan pakan flushing bisa dilihat dari perubahan bobot badan induk, angka kebuntingan, tingkat kematian cempe, dan pertumbuhan (pertambahan bobot badan) serta populasi ternak dalam jangka panjang.

\section{HASIL DAN PEMBAHASAN}

Kegiatan pengabdian yang sudah dilakukan sampai dengan saat ini antara lain adalah melakukan kegiatan sosialisasi, pendidikan masyarakat, pemberdayaan peternak, serta monitoring dan evaluasi hasil kegiatan. Kegiatan pengabdian sudah berjalan selama 7 bulan, tim pengabdian secara rutin melakukan pendampingan dan kunjungan lapangan serta diskusi dalam melaksanakan kegiatan. Kegiatan diawali dengan silaturahmi kepada peternak yang ada di SPR dan perangkat desa setempat. Kegiatan ini dilakukan guna memperoleh perizinan, selain itu juga disampaikan mengenai rencana dan jadwal kegiatan yang nantinya akan dilakukan bersama antara tim dengan petanipeternak baik yang tergabung di SPR maupun bagi masyarakat desa secara umum.

Respon yang diperoleh dari para pengurus SPR maupun perangkat desa cukup positif dan antusias. Kegiatan ini dirasa sangat sesuai dengan visi dan misi SPR maupun Pemerintah Desa Karangdukuh yaitu dalam rangka mengembangkan sektor peternakaan sebagai salah satu penggerak perekonomian masyarakat pedesaan yang selama ini masih banyak didominasi dari sektor kerajinan/pembuatan bata merah. Selama ini sektor pembuatan bata merah justru merusak lingkungan terutama lahan persawahan yang 
subur. Sehingga pemerintah dan masyarakat desa berharap dengan pengembangan sektor peternakan ini akan dapat menjadi alternatif dan solusi dalam rangka menghidupkan kembali lahan-lahan pertanian, karena peternakan merupakan bagian (sub sektor) yang tidak terpisahkan dari kegiatan pertanian.

Berdasarkan laporan (Budisatria \& Udo, 2013), Program Pengentasan Kemiskinan Berbasis Bantuan Ternak Kambing 1 Paket (1 ekor jantan dan 4 ekor betina) di Jawa Tengah memberi kontribusi yang berharga bagi pendapatan tunai dan status sosial penerima. Anggota kelompok sukses memiliki nilai tambah 2,5 kali lebih tinggi dari pada kelompok yang tidak menerima. Semua peternak sepakat bahwa program bantuan berbasis kambing bermanfaat dalam memperbaiki kondisi ekonomi mereka. Faktor yang mempengaruhi keberhasilan adalah persiapan peternak sebelum menerima bantuan, pengalaman beternak, dan manajemen yang dipraktikkan. Faktor eksternal adalah dukungan pemerintah, persediaan lahan, dan pengelolaan (kelembagaan) kelompok ternak tani. Faktor ternak sendiri adalah kemampuan beradaptasi, tingkat kematian rendah, dan jumlah ternak yang dibagikan ke satu peternak.

\subsection{Sosialisasi}

Kegiatan sosialisasi antara tim dan peternak sasaran telah dilakukan. Sosialiasi ini bertujuan untuk menyampaikan mengenai rencana, tujuan, dan metode kegiatan pengabdian kepada seluruh peternak di SPR. Kegiatan sosialisasi dilaksanakan bersama dangan acara rutin pertemuan kelompok SPR sehingga penyampaiannya dapat optimal pada seluruh anggota. Tim pengabdian juga memberikan pretest bagi para peternak pada saat sosialisasi. Pretest yang diberikan berupa pertanyaan-pertanyaan dasar untuk mengetahui banyaknya informasi yang dimiliki peternak dan sejauh mana mereka mengetahui mengenai materi-materi pengabdian seperti konsep breeding center dan pakan flushing. Hasil kegiatan sosialisasi ini adalah respon yang sangat positif dari seluruh anggota SPR terhadap rencana kegiatan pengabdian, dengan demikian peternak akan termotivasi dan bersemangat untuk mengikuti rangkaian kegiatan pengabdian. sementara itu, hasil pretest dapat dilihat pada Tabel 1. 
Tabel 1. Hasil pretest peternak

\begin{tabular}{|c|c|c|c|}
\hline \multirow{2}{*}{ No } & \multirow{2}{*}{ Pertanyaan } & \multicolumn{2}{|c|}{ Persentase } \\
\hline & & Ya & Tidak \\
\hline 1 & Apakah Bapak/ Ibu tahu tentang istilah breeding center? & 21.43 & 78.57 \\
\hline 2 & $\begin{array}{l}\text { Apakah Bapak/Ibu mengetahui manfaat adanya breeding center untuk } \\
\text { ternak? }\end{array}$ & 21.43 & 78.57 \\
\hline 3 & $\begin{array}{l}\text { Apakah Bapak/Ibu tahu mengapa kambing penjantan } \\
\text { disediakan/dipelihara dalam breeding center? }\end{array}$ & 21.43 & 78.57 \\
\hline 4 & $\begin{array}{l}\text { Apakah Bapak/Ibu tahu manfaat memelihara kambing pejantan dalam } \\
\text { breeding center? }\end{array}$ & 14.29 & 85.71 \\
\hline 5 & $\begin{array}{l}\text { Apakah Bapak/Ibu tahu fungsi membawa kambing betina ke dalam } \\
\text { breeding center? }\end{array}$ & 14.29 & 85.71 \\
\hline 6 & $\begin{array}{l}\text { Apakah Bapak/Ibu tahu bahwa } 97 \text { ystem perkawinan kambing yang } \\
\text { ideal dapat terjadi di dalam breeding center? }\end{array}$ & 21.43 & 78.57 \\
\hline 7 & Apakah Bapak/Ibu tahu ciri-ciri kambing betina sedang birahi? & 50.00 & 50.00 \\
\hline 8 & $\begin{array}{l}\text { Apakah Bapak/Ibu tahu tanda-tanda kambing betina sedang/sudah } \\
\text { bunting? }\end{array}$ & 57.14 & 42.86 \\
\hline 9 & Apakah Bapak/ Ibu tahu tentang istilah flushing? & 21.43 & 78.57 \\
\hline 10 & $\begin{array}{l}\text { Apakah Bapak/Ibu mengetahui manfaat pemberian flushing untuk } \\
\text { ternak bunting? }\end{array}$ & 21.43 & 78.57 \\
\hline 11 & Apakah Bapak/Ibu pernah membuat flushing? & - & 100.00 \\
\hline 12 & Apakah Bapak/Ibu tahu bagaimana cara membuat flushing? & - & 100.00 \\
\hline 13 & Apakah Bapak/Ibu tahu bahan-bahan penyusun flushing? & - & 100.00 \\
\hline 14 & $\begin{array}{l}\text { Apakah Bapak/ Ibu tahu tentang } 97 \text { ystem } \text { recording/pencatatan } \\
\text { ternak? }\end{array}$ & - & 100.00 \\
\hline 15 & $\begin{array}{l}\text { Apakah Bapak/ Ibu tahu tentang manfaat melakukan } \\
\text { recording/pencatatan ternak? }\end{array}$ & - & 100.00 \\
\hline
\end{tabular}

Sumber: Data primer diolah, Desa Karangdukuh, Klaten, 2017

Hasil pretest memberikan gambaran mengenai pemahaman peternak dengan materi-materi pengabdian masih minim, pengetahuan mengenai konsep breeding center secara persentase sebanyak 21,43\%, sedangkan sisanya sebanyak $78,57 \%$ belum memahami dan belum pernah mengetahui. Sementara pemahaman mengenai fungsi pejantan di dalam breeding center hanya 14,29\% saja. Namun yang menarik bahwa ada lebih dari $50 \%$ peternak memahami dan mengetahui ciri-ciri atau tanda-tanda visual kambing yang sedang birahi dan bunting. Tentu hal ini mereka peroleh dari pengalaman beternak yang sudah dilakukan selama beberapa tahun. Sebanyak 78,57\% peternak belum mengetahui definisi atau istilah dan manfaat dari flushing sebagai pakan kambing, namun ada 21,43\% yang sudah mengetahuinya, mungkin saja informasi tersebut mereka peroleh karena pernah mendengar atau bersumber dari internet. 
Sementara $100 \%$ peternak belum pernah membuat dan menyusun pakan flushing, begitu juga dengan kegiatan pencatatan atau recording ternak. Dengan adanya informasi berdasarkan hasil pretest ini, maka tim akan melakukan penyuluhan dengan memaparkan seluruh materi kegiatan pengabdian yang terkait dengan pemeliharaan ternak kambing, sehingga akan meningkatkan pemahaman dan pengetahuan peternak.

\subsection{Penyuluhan dan Demonstrasi}

Kegiatan penyuluhan dilaksanakan pada sore hari, dimana para petani-peternak dan masyarakat desa mempunyai waktu yang cukup, karena sudah pulang dan selesai bekerja. Kegiatan ini cukup mendapat respon yang sangat positif, tidak hanya peternak kambing yang tergabung di SPR saja yang hadir, namun juga dari masyarakat umum (warga desa) Karangdukuh, bahkan turut hadir pula para ibu-ibu yang belum mempunyai ternak. Tercatat lebih dari 30 peserta pada kegiatan ini.Selain melakukan penyuluhan dengan beberapa materi terkait pemeliharaan kambing, tim juga membagikan pada peternak berupa buku panduan praktis "Keternak Kambing di Pedesaaan" sebagai modul yang dapat dimanfaatkan untuk belajar secara mandiri, buku tersebut disusun dengan bahasa yang sederhana dan mudah untuk dibaca, dipahami, dan diaplikasikan oleh peternak.

Demonstrasi pembuatan pakan flushing dilaksanakan setelah kegiatan penyuluhan selesai. Kegiatan ini dilaksanakan di rumah anggota SPR pada malam hari karena berlangsung di bulan Ramadhan, sehingga lebih optimal baik untuk aktivitasnya maupun dari jumlah kehadiran pesertanya. Kegiatan ini diikuti beberapa peternak anggota SPR sejumlah 15 orang, sedangkan dari tim dihadiri oleh mahasiswa asisten.

Bahan pakan flushing yang digunakan disajikan pada Tabel 2. Metode pembuatan flushing adalah sebagai berikut: 1) rumput gajah dicacah untuk memperkecil ukuran partikel dan mempermudah proses fermentasi, 2) hasil potongan kemudian diletakkan pada alas plastik (terpal) selanjutnya dicampur dengan bahan pakan lain, starter Em4 dicampur terlebih dahulu dengan penambahan air secukupnya sampai homogen kemudian disiramkan pada campuran bahan pakan tersebut, 3) setelah semua bahan tercampur, dimasukkan ke dalam drum plastik kapasitas 50 liter dan dipadatkan untuk mengurangi adanya udara. 4) drum kemudian ditutup rapat selama dua sampai 
tiga minggu untuk berlangsungnya proses fermentasi secara optimal. 5) pakan flushing dibuka dan dilakukan pengecekan kualitas. Pakan yang jadi ditandai dengan bau segar hijauan dan tidak adanya jamur berwarna putih. Adaptasi pakan dilakukan dengan pemberian bertahap pada kambing. Pembuatan pakan flushing dilakukan sepenuhnya oleh peternak dengan didampingi dan diarahkan oleh tim mahasiswa pendamping kegiatan.

Flushing bertujuan meningkatkan nilai gizi atau nutrien pakan sehingga dapat meningkatkan produktivitas ternak, terutama memperbaiki kondisi induk. Kurangnya ketersediaan hijauan terutama tanaman legum di sekitar lokasi menjadi kendala penyediaan pakan tinggi nutrien, oleh karena itu kegiatan pembuatan flushing sangat tepat sebagi alternatif solusi. Bahan pakan yang digunakan terdiri dari hijauan, konsentrat, dan aditif pakan. Hijauan terdiri dari rumput Gajah, yang berasal dari lahan kelompok namun diasumsikan harga per kg sebessar Rp 250,- sebagai pengganti biaya perawatan dan pemeliharaan rumput. Konsentrat yang digunakan terdiri dari kopra sebagai sumber protein serta dedak padi, onggok kering, dan molases sebagai sumber energi. Aditif pakan yang digunakan berupa starter Em4 agar proses fermentasi lebih efektif. Total pakan yang dibuat sebanyak $200 \mathrm{~kg}$.

Tabel 2. Komposisi, harga dan feed cost pembuatan flushing

\begin{tabular}{lrccr}
\hline Bahan pakan & $\begin{array}{c}\text { Persentase } \\
(\mathbf{\%})\end{array}$ & $\begin{array}{c}\text { Berat } \\
(\mathbf{k g})\end{array}$ & $\begin{array}{c}\text { Harga } \\
(\mathbf{R p} / \mathbf{k g})\end{array}$ & $\begin{array}{c}\text { Total } \\
\text { harga }(\mathbf{R p})\end{array}$ \\
\hline Kopra & 10 & 20 & 3.500 & 70.000 \\
Dedak padi & 5 & 10 & 2.500 & 25.000 \\
Onggok kering & 5 & 10 & 2.500 & 25.000 \\
Molases & 3 & 6 & 5.000 & 30.000 \\
Em4 & 0,5 & 1 & 20.000 & 20.000 \\
Rumput gajah & 76,5 & 153 & 250 & 38.250 \\
Total & & & & 208.250 \\
\hline
\end{tabular}

Sumber: Data primer, Desa Karangdukuh, Klaten, 2017

Berdasarkan Tabel 2, diketahui bahwa total harga untuk pembuatan $200 \mathrm{~kg}$ (asfeed) membutuhkan biaya Rp 208.250, sehingga diperoleh harga total sebesar Rp 1.041/kg. Harga tersebut masih layak dan menguntungkan apabila dihitung dan dibandingkan dengan peningkatan produktivitas yang dihasilkan baik dari peningkatan bobot badan maupun panen anak (cempe). Pakan tersebut akan digunakan untuk induk- 
induk yang dipelihara di breeding center untuk memperbaiki kondisi tubuhnya dan kondisi reproduksinya, dan dapat juga dimanfaatkan untuk ternak yang sedang digemukan (fattening). Sementara itu hasil analisis proksimat pakan setelah 21 hari (3 minggu) di laboratorium Ilmu Makanan Ternak, Fakultas Peternakan UGM diperoleh kadar bahan kering (BK) 84,50\%, kadar abu 12,90\%, kadar protein kasar (PK) 9,82\%, serat kasar (SK) 19,36\% dan bahan eter tanpa nitrogen (BETN) 54,35\%. Hasil analisis proksimat terkait nilai gizi dari pakan yang dibuat tidak jauh berbeda jika dibandingkan dengan pakan flushing yang dibuat oleh (Socheh et al., 2011) yaitu kandungan BK sebesar 89,60\% dan PK 9,88\%, namun angka PK tersebut masih lebih rendah jika dibandingkan dengan hasil dari (Suwignyo et al., 2015), pada pakan komplit yaitu dengan PK sebesar 11,00\%

Flushing nyata bermanfaat dalam usaha untuk meningkatkan kemungkinan berhasilnya perkawinan, mengurangi angka kematian anak prasapih serta menambah kemungkinan kelahiran anak kembar. Pemberian 7,10\% pakan tambahan berupa pakan penguat dengan kandungan protein kasar 17,34\%, lemak serat kasar 18,59\%. Selama 30 hari sebelum dikawinkan dan 30 hari sebelum ternak melahirkan (500 g/ekor/hari). Menunjukkan bahwa perbaikan pakan dengan teknologi flushing menghasilkan kemungkinan kebuntingan yang lebih banyak dibandingkan tidak dilakukan flushing (50\% vs 44,89\%). Hal yang demikian juga berakibat pada jumlah kelahiran kembar; yaitu terjadi kelahiran kembar sebesar 30,77\% dibandingan yang tidak yaitu 18,18\%. Rata-rata jumlah anak per kelahiran pada kambing yang diperbaiki kualitas ransumnya adalah 1,30 ekor; sedangkan yang tidak sebanyak 1,18 ekor (Wardhani et al., 1997). Mengingat bahwa tujuan peternak memelihara kambing untuk menghasilkan cempe, maka perbaikan pakan dengan cara flushing ini terbukti lebih menguntungkan. Induk kambing yang diujicoba dengan pemberian pakan flushing memberi dampak terhadap kemunculan birahi, semenjak adanya breeding center dan pakan flushing dari bulan September hingga bulan Oktober sebanyak 5 ekor induk menunjukan birahi dan sudah dikawinkan. 


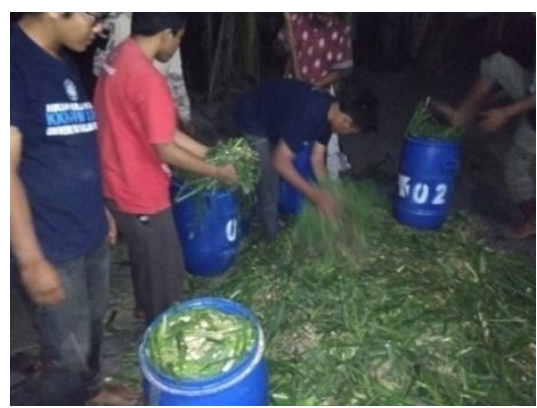

Sumber: Data primer diolah (2017)

Gambar 1. Demonstrasi dan pelatihan pembuatan flushing

\subsection{Pemberdayaan Peternak}

Peternak bertanggungjawab sepenuhnya pada pembangunan breeding center, mulai dari desain kandang, penyediaan bahan, tenaga kerja hingga pembangunannya secara bergotong royong. Kandang kawin yang dibuat berkapasitas 20 ekor. Selain kandang kawin, pada area breeding center seluas $6,250 \mathrm{~m}^{2}$ tersebut juga dibuatkan instalasi listrik, dan juga sumur bor, karena kendala utama di lokasi tersebut adalah tidak tersedianya air bersih. Optimalisasi area breeding center dengan dilengkapi engembangan kebun legum sebagai sumber hijauan pakan ternak kambing yang berkualitas tinggi. Permasalahan terkait ketersediaan pakan hijauan untuk kambing menjadi kendala utama dalam pengembangan ternak kambing di desa tersebut. Adanya kebun legum tersebut, maka diharapkan ketersediaan hijauan pakan akan tetap kontinyu setiap musim. Bibit legum yang ditanam adalah Indigofera sp. dan Caliandra, kedua jenis hijauan tersebut merupakan yang terbaik dan potensial untuk dikembangan di area tersebut. Bibit legum yang ditanam adalah 500 bibit Indigofera sp. dan 500 bibit Caliandra. Bibit legum diperoleh dari Balai Inseminasi Buatan Daerah (BIBD) Kabupaten Sleman. Lokasi penanamannya seluas $1400 \mathrm{~m}^{2}$ yang sudah disipkan oleh pemerintah desa. Kegiatan penanaman dilakukan secara gotong-royong, pemeliharaan hijauan dengan penyiraman dan penyemaian gulma dibuat dengan cara piket dan terjadwal secara bergantian dan rutin oleh masing-masing peternak.

Hijauan Pakan Ternak (HPT) merupakan salah satu hal yang sangat penting bagi peternakan kambing. Tanpa ketersediaan pakan yang baik, maka kambing tidak berproduksi secara optimal. Oleh karena itu, diperlukan suatu cara yang tepat untuk 
mengatur agar supaya HPT tidak terganggu pengadaannya, HPT ternak disukai oleh kambing adalah Indigofera sp. dan Caliandra (Siagian, 2017; Tarigan, 2011).

Indigofera sp. tergolong tanaman leguminosa yang bisa tumbuh pada tanah yang kurang subur dan tahan terhadap kemarau panjang. Pertumbuhannya cepat, pada umur 12 bulan bisa mencapai $2 \mathrm{~m}$. Produksi Indigofera sp. berumur satu tahun dengan jarak tanam $1 \times 0,5 \mathrm{~m}$ dapat menghasilkan produksi bahan kering 33,25 ton/ha/tahun dengan interval pemotongan 3 bulan sekali dengan tinggi pemotongan 1,5 $\mathrm{m}$ di atas permukaan tanah. Daun Indigofera merupakan hijauan makanan ternak yang sangat potensial, dengan kandungan protein kasar rata-rata 23,20\%, bahan organik 90,68\%, NDF $36,72 \%$, fosfor $0,83 \%$ dan kandungan kalsium 1,23\% (Tarigan, 2011).

Caliandra dapat mencapai tinggi 8 mdan tumbuh di dataran rendah hingga ketinggian $1.500 \mathrm{mdpl}$, toleran terhadap tanah yang kurang subur, dapat tumbuh cepat, dan berbintil akar sehingga mampu menahan erosi tanah dan air. Berperan sebagai sumber protein. Penanaman Caliandra pada tanah-tanah yang kurang produktif dapat menekan pertumbuhan gulma (Siagian, 2017). Ada baiknya pada saat pemberian HPT tersebut secara campur. Hal ini bertujuan agar kandungan yang berada di dalam masingmasing tanaman dapat saling melengkapi, sehingga kambing akan merasa tercukupi kandungan gizi maupun proteinnya. Selain itu juga akan meminimalkan kambing merasa bosan makan apabila disajikan dalam satu jenis tanaman saja secara berulangulang (Siagian, 2017)

Setelah kandang kawin berdiri maka tim menyiapkan pejantan unggul yang akan digunakan sesuai dengan bangsa kambing yang dipelihara. Selama ini, anggota kelompok ternak melakukan perkawinan ternak kambing dengan metode inseminasi buatan dengan biaya Rp 50.000 untuk sekali perkawinan. Biaya tersebut tentu dirasa cukup besar bagi anggota kelompok, belum lagi apabila tidak terjadi kebuntingan sehingga harus melakukan IB berulang. Selain perkawinan dengan metode IB, peternak juga melakukan kawin alam, dalam hal ini pejantan yang digunakan belum tentu memiliki kualitas yang baik, karena hanya tersedia terbatas dan tidak pernah diganti, tentu saja hal tersebut dapat mengakibatkan terjadinya perkawinan sedarah atau inbreeding sehingga dapat menurunkan mutu genetik ternak kambing yang ada di desa Karangdukuh. 
Pejantan yang dipilih adalah pejantan kambing Peranakan Etawah (PE) ras kaligesing, karena sebagian bangsa kambing yang dimiliki peternak berdasarkan pendataan adalah kambing PE dan bligon, serta beeberapa adalah kambing kacang. Selain itu kambing PE juga dikenal sebagai bangsa terbaik untuk ternak kambing dan peminat dari kambing PE tersebut lumayan besar di pasaran. Diharapkan terjadi peningkatan kualitas anak yang dihasilkan melalui skema grading up yang akan berdampak pada peningkatan harga jual kambing milik peternak. Selain itu, dengan adanya dropping pejantan kambing, dapat menarik minat anggota kelompok ternak untuk memindahkan ternak kambing ke lokasi breeding center.

Pola perkawinan di kandang kawin juga diatur dan dicatat di buku recording yang sebelumnya telah disosialisasikan oleh tim pengabdian kepada anggota kelompok. Apabila kambing betina terlihat tanda birahi, segera dipindah ke kandang kawin kemudian diambil sehari kemudian. Apabila kambing betina tidak pernah terlihat tanda birahi (silent heat) maka kambing betina tersebut dimasukkan ke dalam kandang kawin selama kurang lebih 20 hari, dengan begitu diharapkan ditengah siklus tersebut kambing jantan dapat mendeteksi birahi. Pencatatan di buku recording juga penting dilakukan untuk mengetahui data perkawinan kambing, sehingga diharapkan dapat menghindari inbreeding. Oleh karena itu, diharapkan melalui penyediaan pejantan unggul dapat mewujudkan daerah Karangdukuh sebagai pusat pengembangan dan pembiakan ternak kambing.

Dropping pakan yang dikhususkan untuk kambing pejantan PE juga dilakukan. Pakan yang diberikan yakni konsentrat berupa Nutrifeed ${ }^{\circledR}$ dan kleci. Pakan tersebut diharapkan dapat menjaga maupun dapat meningkatkan kinerja kambing pejantan. Untuk selanjutnya pakan pejantan akan disuplai secara swadaya oleh pternak melalui kas kelompok/SPR. Selain itu pada area breeding center juga dibuatkan poster sebagi media pengingat agar mudah diingat dan diaplikasikan oleh peternak. Kegiatan droping disajikan pada Gambar 2. 

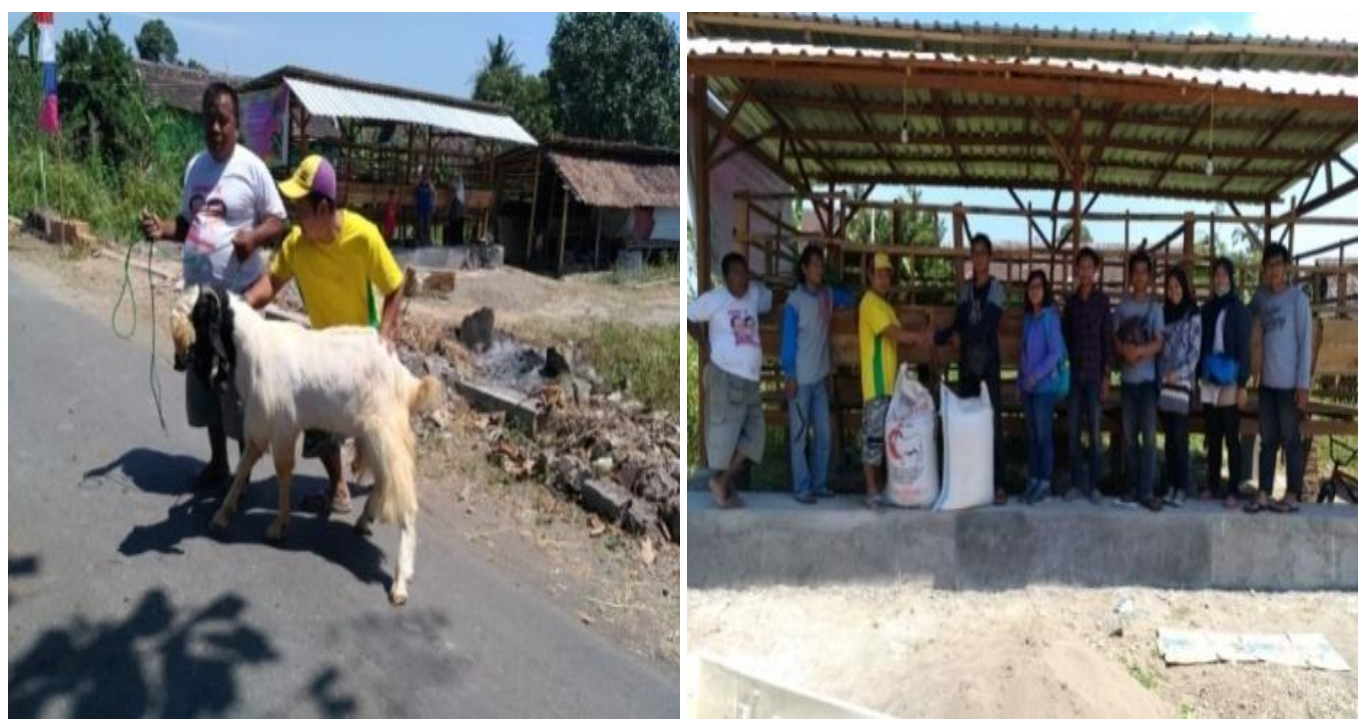

Sumber: Data primer diolah (2017)

Gambar 2. Kegiatan dropping pejantan dan pakan di area breeding center

\subsection{Pencegahan Penyakit}

Status kesehatan ternak diidentifikasi dengan melakukan pendataan riwayat dan kondisi visual ternak. Kemudian untuk kegiatan pencegahan penyakit dilakukan vaksinasi terhadap ternak kambing. Kegiatan vaksinasi dengan pemberian obat cacing dan pemberian multi vitamin. Sedangkan untuk pengobatan dilakukan apabila ditemukan ternak yang menderita sakit, antara lain kembung, gudik atau scabies. Kegiatan ini dilakukan dengan mendatangi ternak secara door to door oleh tim mahasiswa pelaksana. Kegiatan pencegahan penyakit juga dilakukan dengan melakukan introduksi macam-macam penyakit yang sering muncul pada ternak kambing, ciri-ciri ternak yang sakit, cara pencegahan penyakit dan cara pengobatan penyakit. Kegiatan dilakukan dengan diskusi pada saat penyuluhan, dan juga disampaikan lewat buku panduan praktis. Riwayat penyakit yang sering muncul adalah kembung dan diare serta sering terjadi keracunan akibat pakan yang diberikan mengandung zat toksik. Dengan adanya konsep breeding center dan flushing diharapkan dapat menanggulangi permasalahan tersebut. Status kesehatan ternak kambing lebih terkontrol.

\subsection{Monitoring dan Evaluasi}

Tahap monitoring dilaksanakan tim pengabdian di tengah-tengah kegiatan berlangsung, yaitu dengan meninjau kondisi ternak, kandang, dan hasil-hasil 
pengabdian yang telah dilakukan oleh tim sebelumnya. Evaluasi kegiatan dilakukan dengan mengadakan posttest. Pertanyaan pada posttest sama dengan pada saat pretest. Hal ini dilakukan untuk mengetahui sejauh mana pemahaman peternak terkait dengan kegiatan pengabdian yang telah dilakukan. Hasil dari pelaksanaan posttest oleh para peternak di Kelompok Kandang Kalimasodo pada akhir kegiatan disajikan pada Tabel 3.

Indikator capaian target berupa partisipasi aktif peternak dalam setiap kegiatan pengabdian yang dilaksanakan terlihat dari respon positif, kemauan untuk mengikuti setiap kegiatan serta sifat gotong royong yang sudah ditunjukan selama kegiatan berlangsung. Indikator capaian target adopsi sistem perkawinan oleh kelompok ternak dan peningkatan kinerja kambing yang dipelihara, sementara pada flushing sudah diuji coba dan dianalisis proksimat. Hasil ujicoba pakan sangat disukai oleh ternak, dan mempunyai kualitas organoleptik yang baik, namun masih kurang dalam kandungan protein kasar. Sehinggap perlu tingkatkan proporsi bahan pakan sumber protein.

Hasil posttest menunjukkan sebagian besar peternak sudah mulai memahami beberapa aspek manajemen budidaya ternak kambing melalui konsep breeding center yang baik, seperti manfaat dan metode dalam konsep breeding center, pemilihan bakalan, manajemen pencatatan (recording), teknologi pakan flushing, pemahaman mengenai tanda-tanda birahi dan bunting pada kambing betina.

Selain dengan pertanyaan posttest, evaluasi kegiatan pengabdian juga dilakukan dengan melakukan survey wawancara terhadap peternak mitra pada saat kegiatan pengabdian berakhir. Hasil tersebut disajikan pada tabel 4, dan peternak merasakan manfaat dari kegiatan pengabdian tersebut. Manfaat yang diperoleh berdasarkan informasi langsung dari peternak adalah dapat membuat pakan yang baik untuk ternak kambing dengan pakan komplit fermentasi yang mudah dan murah, dapat mengawinkan ternaknya dengan pejantan unggul. Terbukti dengan adanya kegiatan pengabdian, peternak yang awalnya enggan memindahkan ternaknya ke kandang terpadu saat ini sudah mau memindahkan ternaknya. Saat ini sudah ada 33 ekor kambing milik peternak (dari total populasi berdasarkan pendataan yaitu 50 ekor) yang sudah dipindahkan ke breeding center dengan tujuan untuk dapat dikawinkan dan memperoleh kebuntingan. Hasilnya angka kebuntingan induk di breeding center mencapai 7 ekor (21\%). 
Sementara itu untuk tanaman legum sudah tumbuh dengan baik, dengan tinggi tanaman mencapai $1 \mathrm{~m}$.

Tabel 3. Hasil posttest peternak

\begin{tabular}{|c|c|c|c|}
\hline \multirow[t]{2}{*}{ No } & \multirow[t]{2}{*}{ Pertanyaan } & \multicolumn{2}{|c|}{ Persentase } \\
\hline & & Ya & Tidak \\
\hline 1 & Apakah Bapak/ Ibu tahu tentang istilah breeding center? & 100.00 & - \\
\hline 2 & $\begin{array}{l}\text { Apakah Bapak/Ibu mengetahui manfaat adanya breeding } \\
\text { center untuk ternak? }\end{array}$ & 100.00 & - \\
\hline 3 & $\begin{array}{l}\text { Apakah Bapak/Ibu tahu mengapa kambing penjantan } \\
\text { disediakan/dipelihara dalam breeding center? }\end{array}$ & 80.00 & 20.00 \\
\hline 4 & $\begin{array}{l}\text { Apakah Bapak/Ibu tahu manfaat memelihara kambing } \\
\text { pejantan dalam breeding center? }\end{array}$ & 80.00 & 20.00 \\
\hline 5 & $\begin{array}{l}\text { Apakah Bapak/Ibu tahu fungsi membawa kambing betina ke } \\
\text { dalam breeding center? }\end{array}$ & 90.00 & 10.00 \\
\hline 6 & $\begin{array}{l}\text { Apakah Bapak/Ibu tahu bahwa sistem perkawinan kambing } \\
\text { yang ideal dapat terjadi di dalam breeding center? }\end{array}$ & 70.00 & 30.00 \\
\hline 7 & $\begin{array}{l}\text { Apakah Bapak/Ibu tahu ciri-ciri kambing betina sedang } \\
\text { birahi? }\end{array}$ & 100.00 & - \\
\hline 8 & $\begin{array}{l}\text { Apakah Bapak/Ibu tahu tanda-tanda kambing betina } \\
\text { sedang/sudah bunting? }\end{array}$ & 100.00 & - \\
\hline 9 & Apakah Bapak/ Ibu tahu tentang istilah flushing? & 100.00 & - \\
\hline 10 & $\begin{array}{l}\text { Apakah Bapak/Ibu mengetahui manfaat pemberian flushing } \\
\text { untuk ternak bunting? }\end{array}$ & 100.00 & - \\
\hline 11 & Apakah Bapak/Ibu pernah membuat flushing? & 100.00 & - \\
\hline 12 & Apakah Bapak/Ibu tahu bagaimana cara membuat flushing? & 100.00 & - \\
\hline 13 & Apakah Bapak/Ibu tahu bahan-bahan penyusun flushing? & 100.00 & - \\
\hline 14 & $\begin{array}{l}\text { Apakah Bapak/ Ibu tahu tentang sistem recording/pencatatan } \\
\text { ternak? }\end{array}$ & 100.00 & - \\
\hline 15 & $\begin{array}{l}\text { Apakah Bapak/ Ibu tahu tentang manfaat melakukan } \\
\text { recording/pencatatan ternak? }\end{array}$ & 20 & 80 \\
\hline
\end{tabular}

Sumber: Data primer diolah, Desa Karangdukuh, Klaten, 2017

Dengan demikian diharapkan peternak dapat melanjutkan apa yang sudah dilakukan selama kegaiatan berlangsung. Kegiatan pendampingan pada Sentra Peternak kambing Rakyat Kebun Wulangreh akan terus menerus dilakukan mengingat adanya kemauan untuk belajar dan sudah dibentuknya area breeding center ternak kambing dengan ketersediaan pejantan, hijauan dan sumber air serta lokasinya yang terpadu dengan kandang kelompok komoditi ternak lainnya. Sehingga menjadi kebanggan dan bukti kemandirian desa dalam upaya menggalakkan peternakan dan pertanian. 
Tabel 4. Hasil evaluasi kegiatan pengabdian

\begin{tabular}{llrr}
\hline No & \multicolumn{1}{c}{ Pertanyaan } & Ya & Tidak \\
\hline $\mathbf{1}$ & $\begin{array}{l}\text { Program pengabdian yang dilakukan sesuai dengan } \\
\text { kebutuhan anggota kelompok ternak }\end{array}$ & $100 \%$ & $0 \%$ \\
$\mathbf{2}$ & $\begin{array}{l}\text { Materi pengabdian yang disampaikan sudah sesuai dengan } \\
\text { yang diharapkan }\end{array}$ & $100 \%$ & $0 \%$ \\
$\mathbf{3}$ & $\begin{array}{l}\text { Metode penyampaian materi pengabdian dan pelatihan sudah } \\
\text { sesuai dengan yang diharapkan }\end{array}$ & $83 \%$ & $17 \%$ \\
$\mathbf{4}$ & $\begin{array}{l}\text { Manfaat yang diperoleh dari kegiatan pengabdian } \\
\mathbf{5}\end{array}$ & $\begin{array}{l}\text { Mengaplikasikan materi pelatihan yang telah diberikan } \\
\text { Sumber: Data primer diolah, Desa Karangdukuh, Klaten, 2017 }\end{array}$ & $0 \%$ \\
\hline Sumb & & $17 \%$ \\
\hline
\end{tabular}

\section{SIMPULAN}

Kegiatan pengabdian sudah berjalan sesuai dengan target dan mendapatkan respon yang sangat positif dari peternak anggota SPR. Peternak secara gotong-royong membangun kandang kawin, instalasi listrik, sumur bor, dan kebun hijauan. Area dan konsep breeding center sudah dimanfaatkan dan dijalankan, peternak sudah mampu membuat flushing dan akan diteruskan secara mandiri. Kegiatan pendampingan akan terus berlanjut secara terus menerus agar kegiatan penerapan konsep breeding center dan penggunaan teknologi pakan (flushing) dapat berjalan dengan baik dan mencapai target kinerja induk kambing yang diinginkan.

\section{UCAPAN TERIMA KASIH}

Kegiatan ini didanai oleh Direktorat Pengabdian Kepada Masyarakat Universitas Gadjah Mada melalui skema "Program Pengabdian Kepada Masyarakat Berbasis Pemanfaatan Hasil Penelitian dan Penerapan Teknologi Tepat Guna” Tahun 2017.

\section{DAFTAR PUSTAKA}

Budisatria, I. G. S., \& Santosa, K. A. (2009). Bangsa-Bangsa Kambing dan Sejarah Perkembangannya di Indonesia. Yogyakarta: CV Bawah Sadar.

Budisatria, I. G. S., \& Udo, H. M. J. (2013). Goat-Based Aid Programme in Central Java: An Effective Intervention for the Poor and Vulnerable? Small Ruminant Research, 109(2-3), 76-83. https://doi.org/10.1016/j.smallrumres.2012.07.019

Budisatria, I. G. S., Udo, H. M. J., Eilers, C. H. A. M., Baliarti, E., \& Zijpp, A. J. Van Der. (2010). Preferences for Sheep or Goats in Indonesia. Small Ruminant Research, 88, 16-22. https://doi.org/10.1016/j.smallrumres.2009.11.002 
Munawaroh, L. L., Budisatria, I. G. S., \& Suwignyo, B. (2015). Pengaruh Pemberian Fermentasi. Buletin Peternakan, 39(3), 167-173.

Ngadiyono, N., Budisatria, I. G. S., \& Sadeli, A. (2014). 4169. Penggunaan Complete Feed Terfermentasi terhadap Produksi Karkas dan Kualitas Kimia Daging Kambing Bligon. Buletin Peternakan, 38(2), 109-115.

Nuraini, Budisatria, I. G. S., \& Agus, A. (2014). Pengaruh Tingkat Penggunaan Pakan Penguat terhadap Performa Induk Kambing Bligon di Peternak Rakyat. Buletin Peternakan, 38(1), 34-41.

Socheh, M., Ismaya, Budisatria, I. G. S., \& Kustantinah. (2011). Pengaruh Flushing Berbasis Pakan Lokal terhadap Pertumbuhan dan Birahi Kambing Kejobong Betina Dewasa. Sains Peternakan, 9 (September), 53-64.

Suwignyo, B., Munawaroh, L. L., \& Budisatria, I. G. S. (2015). Effect of Material and Fermentation Time on Quality and Digestibility of Complete Feed , Average Daily Gain of Bligon Goat and Farmer's Income, 40(March), 23-30.

Wardhani, N. K., Musofie, A., \& Harwono, R. (1997). Upaya Perbaikan Pakan Dengan Metode Flushing. Seminar Nasional Peternakan Dan Veteriner 1997, 48-54.

Widi, T. S. M., Baliarti, E., Ariyanti, F., Ngadiyono, N., Budisatria, I. G. S., Panjono, \& Yulianto, M. D. E. (2016). Kinerja Anak Kambing Bligon Setelah Introduksi Pejantan Unggul di Kelompok Ternak Purwo Manunggal, Gunungkidul. Jurnal Sains Veteriner, 34(2), 251-258.

\section{DAFTAR LAMAN}

Tarigan, A. 2011. Tanaman Indigofera sp untuk Ternak Kambing. Agroinovasi. Sinartani. Edisi 14-20 desember 2011. Loka Penelitian Kambing Potong Sei Putih. Diakses dari: http://www.litbang.pertanian.go.id/download/one/218/file/TanamanIndigofera-sp-untu.pdf

Siagian B Toman. 2017. Pakan Ternak Kambing. Balai Besar Pembibitan Ternak unggul dan Hijauan Pakan Ternak Baturaden.

Diakses dari: http://bbptusapiperah.ditjenpkh.pertanian.go.id/2017/07/pakan-ternakkambing/ 